\title{
TINJAUAN KEBUTUHAN TENAGA KERJA PETUGAS REKAM MEDIS BERDASARKAN METODE WORKLOAD INDICATOR OF STAFFING NEEDS (WISN) DI KLINIK RAWAT INAP RAMDANI HUSADA
}

\author{
Description of Medical Record Officer Requirement Based on WISN (Workload \\ Indicator of Staffing Needs) Method on Ramdani Husada Inpatient Clinic
}

\author{
Irma Wulandari ${ }^{1 *}$ \\ Fitri Indahsari ${ }^{2}$ \\ *IDosen Sub Departeman D3 \\ Rekam Medik dan Informasi \\ Kesehatan, STIKes Widya Cipta \\ Husada Malang, Jawa Timur, \\ Indonesia \\ 2Alumni Sub Departeman D3 \\ Rekam Medik dan Informasi \\ Kesehatan, STIKes Widya Cipta \\ Husada Malang, Jawa Timur, \\ Indonesia
}

*email:

irmarmikwch@gmail.com

Kata Kunci:

Kebutuhan Tenaga Kerja

Rekam Medis

WISN

\section{Keywords:}

Labor Need's

Medical Records

WISN

\begin{abstract}
Abstrak
Rekam medis adalah salah satu bagian terpenting di suatu pelayanan kesehatan yang harus didukung dengan jumlah sumber daya manusia yang memadai, sehingga diperlukan perhitungan kebutuhan tenaga kerja yang tepat. Kegiatan rekam medis di Klinik Rawat Inap Ramdani Husada tidak dikerjakan oleh petugas dengan kualifikasi pendidikan rekam medis, namun dikerjakan oleh petugas dengan kualifikasi Pendidikan SMA, D-I Kebidanan, dan D-III Kebidanan. Tujuan penelitian untuk mengetahui gambaran kebutuhan tenaga kerja petugas rekam medis berdasarkan metode WISN (Workload Indicator Of Staffing Need) di Klinik Rawat Inap Ramdani Husada . Desain penelitian menggunakan kuantitatif deskriptif dengan pendekatan cross sectional. Populasi dan sampel penelitian adalah seluruh petugas yang melakukan kegiatan rekam medis sebanyak 3 orang meliputi manager klinik, kepala administrasi, dan staf administrasi. Hasil penelitian menunjukkan waktu kerja tersedia yaitu I.953 jam/ tahun atau setara dengan II7.180 menit/tahun, standar beban kerja yang tidak sesuai dengan jumlah petugas yang tersedia, standar kelonggaran sebesar I,70 tenaga kerja. Sehingga kebutuhan tenaga kerja petugas rekam medis berdasarkan metode WISN sebanyak 9 tenaga kerja. Berdasarkan hasil penelitian terdapat kesenjangan antara teori dengan praktek, dimana pada Klinik Rawat Inap Ramdani Husada tidak menggunakan metode WISN ataupun metode lain untuk perencanaan tenaga kerjanya. Disarankan agar Klinik Rawat Inap Ramdani Husada melakukan perencanaan yang lebih dalam yang berkaitan dengan tenaga kerja khususnya petugas rekam medis untuk meningkatkan produktifitas kerja serta menurunkan resiko kelelahan pada petugas.
\end{abstract}

\begin{abstract}
The medical record is one of the most important parts in a health service which must be supported by an adequate number of human resources, so it is necessary to calculate the exact workforce requirements. Medical record activities at Ramdani Husada Inpatient Clinic are not done by officers with medical record education qualifications, but are carried out by officers with qualifications of high school education, midwifery diploma and midwifery diploma. The research objective was to describe the need for medical record personnel based on the WISN (Workload Indicator of Staffing Need) method at the Ramdani Husada Inpatient Clinic. The research design used descriptive quantitative with cross sectional approach. The population and sample of the study were all officers who carried out medical record activities as many as 3 people including the clinic manager, head of administration, and administrative staff. The results showed that the available work time was I,953 hours I year or equivalent to 117,180 minutes / year, the workload standard was not in accordance with the number of available officers, the allowance standard was 1.70 workers. So that the need for medical record officers based on the WISN method is 9 workers. Based on the research results, there is a gap between theory and practice, where the Ramdani Husada Inpatient Clinic does not use the WISN method or other methods for planning its workforce. It is suggested that the Ramdani Husada Inpatient Clinic do a deeper planning related to the workforce, especially for medical record officers to increase work productivity and reduce the risk of fatigue in officers.
\end{abstract}

(c) year The Authors. Published by Institute for Research and Community Services Universitas Muhammadiyah Palangkaraya. This is Open Access article under the CC-BY-SA License (http://creativecommons.org/licenses/by-sa/4.0/). DOI: https://doi.org// 0.33084/jsm.vxix.xxx. 


\section{PENDAHULUAN}

Salah satu indikator keberhasilan fasilitas pelayanan kesehatan yang efektif dan efisien adalah tersedianya SDM yang cukup dengan kualitas yang tinggi, profesional sesuai dengan fungsi dan tugas setiap personel. Ketersediaan SDM fasilitas pelayanan kesehatan disesuaikan dengan kebutuhan fasilitas pelayanan kesehatan berdasarkan tipe fasilitas pelayanan kesehatan dan pelayanan yang diberikan kepada masyarakat. Ketersediaan SDM di fasilitas pelayanan kesehatan harus menjadi perhatian pimpinan. Salah satu upaya penting yang harus dilakukan pimpinan fasilitas pelayanan kesehatan adalah merencanakan kebutuhan SDM secara tepat sesuai dengan fungsi pelayanan setiap unit, bagian, dan instalasi rumah sakit (Saputri, 2009).

Perencanaan SDM adalah suatu proses sistematis yang digunakan untuk memprediksi permintaan dan penyediaan SDM di masa datang. Melalui program perencanaan SDM yang sistematis dapat diperkirakan jumlah dan jenis tenaga kerja yang dibutuhkan pada setiap periode tertentu sehingga dapat membantu bagian SDM dalam perencanaan rekrutmen, seleksi, serta pendidikan dan pelatihan (Ningsih, 20I2). Salah satu metode perencanaan kebutuhan tenaga adalah Workload Indicator Of Staffing Need (WISN), yaitu metode perhitungan kebutuhan SDM kesehatan berdasarkan pada beban pekerjaan nyata yang dilaksanakan oleh tiap kategori SDM kesehatan pada tiap unit kerja di fasilitas pelayanan kesehatan. Kelebihan metode ini mudah dioperasikan, mudah digunakan, secara teknis mudah diterapkan, komprehensif dan realistis ((Ningsih, 20I2)).

Hasil observasi pada saat studi pendahuluan di Klinik Rawat Inap Ramdani Husada Kepanjen hari Selasa tanggal 23 Maret 2020, diketahui bahwa terdapat 3 petugas rekam medis, dengan latar belakang pendidikan bukan pendidikan rekam medis melainkan Pendidikan SMA, D-I Kebidanan, dan D-III Kebidanan. 3 petugas rekam medis tersebut merangkap semua sub kerja rekam medis mulai dari pendaftaran pasien, coding,mengambil dan mengembalikan berkas rekam medis di ruang filing, serta input klaim BPJS rawat jalan. Melihat hal tersebut menyebabkan pekerjaan pelaporan menjadi terbengkalai.

Besarnya peranan instalasi rekam medik dalam menunjang sistem informasi pelayanan Kesehatan, maka perencanaan kebutuhan SDM harus sesuai dengan kebutuhan baik dari segi jenis dan jumlahnya. Oleh sebab itu harus dilakukan analisis kebutuhan tenaga, karena kelebihan tenaga akan mengakibatkan terjadinya penggunaan waktu kerja yang tidak produktif atau sebaliknya kekurangan tenaga akan mengakibatkan beban kerja yang berlebihan. Jika permasalahan ini tidak segera dicari jalan keluarnya, maka pekerjaan pada Instalasi rekam medik akan mengalami keterlambatan dalam memberikan informasi kesehatan maupun pelayanan serta menurunkan risiko kelelahan pada petugas. Berdasarkan latar belakang di atas, peneliti tertarik melakukan penelitian tentang "Tinjauan Kebutuhan Tenaga Kerja Petugas Rekam Medis Berdasarkan Metode Workload Indicator of Staffing Needs (WISN) di Klinik Rawat Inap Ramdani Husada”.

\section{METODOLOGI}

\section{Desain Penelitian}

Desain penelitian menggunakan metode kuantitatif deskriptif dengan pendekatan cross sectional, yaitu suatu metode penelitian yang dilakukan dengan tujuan utama untuk membuat gambaran atau deskripsi tentang suatu keadaan secara objektif yang mengungkapkan gambaran masalah yang terjadi pada saat penelitian ini berlangsung. Pendekatan kuantitatif ini berupa perhitungan jumlah kebutuhan tenaga kerja petugas rekam medis berdasarkan rumus perhitungan WISN (Workload Indicator Of Staffing Need).

Tempat Dan Waktu PenelitianPenelitian dilakukan di unit rekam medis Klinik Rawat Inap Ramdani Husada yang berada di Jl. Raya Jatikerto No. 78, Kecamatan Kromengan Kabupaten Malang. 
Penelitian dilaksanakan pada bulan April - Juli tahun 2020.

\section{Populasi Dan Sampel}

Populasi dan sampel pada penelitian ini adalah seluruh petugas rekam medis sejumlah 3 orang. Teknik pengambilan sampel menggunakan total sampling, yaitu teknik penentuan sampel dengan cara mengambil seluruh anggota populasi sebagai responden atau sampel (Sugiyono, 201 I:68).

\section{Analisis Data}

Analisis yang digunakan adalah analisis deskriptif. Analisis deskriptif digunakan untuk menganalisis data dengan cara mendeskripsikan atau menggambarkan data yang telah terkumpul sebagaimana adanya tanpa bermaksud membuat kesimpulan yang berlaku untuk umum atau generalisasi (Notoatmodjo, 2010:182). Data kebutuhan tenaga kerja petugas rekam medis dianalisis menggunakan mean (nilai rata-rata) dan perhitungan menggunakan metode WISN. Hasil dalam perhitungan ditampilkan dalam bentuk tabel.

\section{HASIL DAN PEMBAHASAN}

HASIL

\section{Kualifikasi Tenaga Kerja di Unit Rekam Medis Klinik Rawat Inap Ramdani Husada}

Tabel I

\begin{tabular}{|c|c|c|c|c|}
\hline $\begin{array}{c}\text { Nama } \\
\text { Jabatan }\end{array}$ & $\begin{array}{l}\text { Kualifikasi } \\
\text { Formal \& } \\
\text { Informal }\end{array}$ & $\begin{array}{c}\text { Tenaga } \\
\text { yang } \\
\text { Dibutuhkan }\end{array}$ & $\begin{array}{c}\text { Tenaga } \\
\text { yang } \\
\text { Ada }\end{array}$ & $\begin{array}{c}\text { Kualifikasi } \\
\text { Pendidikan } \\
\text { yang ada }\end{array}$ \\
\hline $\begin{array}{l}\text { Kepala } \\
\text { Sub Bag } \\
\text { Rekam } \\
\text { Medis }\end{array}$ & $\begin{array}{l}\text { D III Rekam } \\
\text { Medis } \\
\text { (Pelatihan ICD } \\
10+\text { pengalaman } \\
\text { kerja minimal } 2 \\
\text { tahun) }\end{array}$ & I & - & - \\
\hline $\begin{array}{l}\text { Staf } \\
\text { Pelapora } \\
n\end{array}$ & $\begin{array}{l}\text { D III Rekam } \\
\text { Medis }\end{array}$ & I & I & $\begin{array}{c}\text { D-III } \\
\text { Kebidanan }\end{array}$ \\
\hline $\begin{array}{l}\text { Staf } \\
\text { Koding } \\
\text { Umum, } \\
\text { Koding } \\
\text { BPJS RI, } \\
\text { Koding } \\
\text { BPJS RJ }\end{array}$ & $\begin{array}{l}\text { D III Rekam } \\
\text { Medis } \\
\text { (Pelatihan ICD } \\
\text { I0) }\end{array}$ & I & - & - \\
\hline $\begin{array}{l}\text { Staf } \\
\text { Filing, } \\
\text { Distribus } \\
\text { i }\end{array}$ & $\begin{array}{l}\text { D III Rekam } \\
\text { Medis / SLTA } \\
\text { Plus }\end{array}$ & I & - & - \\
\hline
\end{tabular}

\begin{tabular}{|c|c|c|c|c|c|}
\hline $\begin{array}{c}\text { Nama } \\
\text { Jabatan }\end{array}$ & $\begin{array}{c}\text { Kualifikasi } \\
\text { Formal \& } \\
\text { Informal }\end{array}$ & $\begin{array}{c}\text { Tenaga } \\
\text { yang } \\
\text { Dibutuhkan }\end{array}$ & $\begin{array}{c}\text { Tenaga } \\
\text { yang } \\
\text { Ada }\end{array}$ & \multicolumn{2}{|c|}{$\begin{array}{c}\text { Kualifikasi } \\
\text { Pendidikan } \\
\text { yang ada }\end{array}$} \\
\hline Staf TPP & SLTA Plus & 2 & 2 & a) & $\begin{array}{l}\text { D-I } \\
\text { Kebi } \\
\text { dana } \\
\text { n } \\
\text { SMA }\end{array}$ \\
\hline & umlah & 6 & 3 & & \\
\hline
\end{tabular}

Berdasarkan tabel I diketahui bahwa staf rekam medis berjumlah 3 orang, dengan latar belakang pendidikan SMK/SLTA, D-I Kebidanan, dan D-III Kebidanan

Tabel 2

\begin{tabular}{|c|c|c|}
\hline $\begin{array}{c}\text { Kategori } \\
\text { Tenaga Kerja }\end{array}$ & $\begin{array}{l}\text { Jumlah } \\
\text { Tenaga } \\
\text { Kerja } \\
\text { (orang) }\end{array}$ & $\begin{array}{c}\text { Keterangan } \\
\text { Merangkap Pekerjaan di } \\
\text { bagian }\end{array}$ \\
\hline $\begin{array}{l}\text { Kepala Unit } \\
\text { Tempat } \\
\text { Pendaftaran } \\
\text { Pasien }\end{array}$ & I & $\begin{array}{l}\text { a. Coding } \\
\text { b. Filing (Penyimpanan dan } \\
\text { Penyediaan DRM) } \\
\text { c. Keuangan }\end{array}$ \\
\hline Pelaporan & $I$ & $\begin{array}{l}\text { a. Filing (Penyimpanan dan } \\
\text { Penyediaan DRM) } \\
\text { b. Coding } \\
\text { c. Pendaftaran } \\
\text { d. Keuangan }\end{array}$ \\
\hline Pendaftaran & $I$ & $\begin{array}{l}\text { a. Filing (Penyimpanan dan } \\
\text { Penyediaan DRM) } \\
\text { b. Keuangan } \\
\text { c. Coding }\end{array}$ \\
\hline
\end{tabular}

$\overline{\text { Berdasarkan pada tabel II, } 3 \text { orang petugas rekam medis }}$ merangkap semua kegiatan perekam medis.

\section{Waktu Kerja Tersedia Petugas Rekam Medis}

Tabel 3

\begin{tabular}{clcl}
\hline Kode & Faktor & Jumlah & Keterangan \\
\hline A & Hari Kerja & 312 & Hari/Tahun \\
\hline B & $\begin{array}{l}\text { Cuti } \\
\text { Tahunan }\end{array}$ & 12 & Hari/Tahun \\
\hline C & $\begin{array}{l}\text { Pendidikan } \\
\text { dan } \\
\text { Pelatihan }\end{array}$ & 0 & Hari/Tahun \\
\hline D & $\begin{array}{l}\text { Hari Libur } \\
\text { Nasional }\end{array}$ & 18 & Hari/Tahun \\
\hline E & $\begin{array}{l}\text { Ketidakhadi } \\
\text { ran Kerja }\end{array}$ & 3 & Hari/Tahun \\
\hline F & $\begin{array}{l}\text { Waktu } \\
\text { Kerja }\end{array}$ & 7 & Jam/Hari \\
\hline
\end{tabular}

Berdasarkan tabel III diketahui bahwa hari kerja didapatkan dari jumlah hari kerja dalam I minggu 
dikalikan jumlah minggu dalam I tahun. Perhitungan sebagai berikut :

Hari Kerja $(A)=$ hari kerja I minggu $\times$ jumlah hari minggu I tahun

$=6$ hari $\times 52$ hari minggu

$=312$ hari per tahun

Berdasarkan data tersebut, maka rumus untuk menghitung jumlah waktu kerja tersedia yaitu :

Waktu Kerja Tersedia $=\{A-(B+C+D+E)\} \times F$

$=\{312-(12+0+18+3)\} \times 7$

$=\{3 \mid 2-(33)\} \times 7$

$=279 \times 7$

$=1.953 \mathrm{jam} /$ tahun

$=1.953 \times 60$ menit

$=117.180$ menit $/$ tahun

Berdasarkan hasil perhitungan di atas, waktu kerja tersedia pada unit rekam medis sebesar 1 I7.180 menit per tahun.

\section{Penetapan Unit Kerja dan Kategori Tenaga} Kerja

\section{Tabel 4}

\begin{tabular}{ll}
\hline Unit Kerja & Kategori Tenaga Kerja \\
\hline Unit Rekam Medis Klinik & Petugas pendaftaran Klinik Rawat \\
Rawat Inap Ramdani & Inap Ramdani Husada \\
\cline { 2 - 2 } Husada & $\begin{array}{l}\text { Petugas filing Klinik Rawat Inap } \\
\text { Ramdani Husada }\end{array}$ \\
\cline { 2 - 2 } & $\begin{array}{l}\text { Petugas coding Klinik Rawat Inap } \\
\text { Ramdani Husada }\end{array}$ \\
\cline { 2 - 2 } & $\begin{array}{l}\text { Petugas pelaporan Klinik Rawat Inap } \\
\text { Ramdani Husada }\end{array}$ \\
\end{tabular}

Berdasarkan tabel IV penetapan unit kerja yaitu di unit rekam medis Klinik Rawat Inap Ramdani Husada dan untuk kategori tenaga kerja yaitu petugas pendaftaran, filing, coding, dan pelaporan.

\section{Perhitungan Standar Beban Kerja Petugas} Rekam Medis

a. Unit Tempat Pendaftaran Pasien (TPP) Tabel V

\begin{tabular}{lccc}
\hline Kegiatan & $\begin{array}{c}\text { Satuan } \\
\text { (per } \\
\text { tahun) }\end{array}$ & Kuantitas & $\begin{array}{c}\text { Rata-rata } \\
\text { Waktu } \\
\text { Perkegiatan } \\
\text { (Menit) }\end{array}$ \\
\hline $\begin{array}{l}\text { Melayani } \\
\text { pendaftaran }\end{array}$ & Pasien & 25.910 & 7 \\
$\begin{array}{l}\text { pasien RJ } \\
\text { dan IGD }\end{array}$ & & & \\
\hline $\begin{array}{l}\text { Melayani } \\
\text { pendaftaran } \\
\text { pasien RI }\end{array}$ & Pasien & $\mathrm{I} .320$ & 15 \\
\hline
\end{tabular}

\section{Tabel VI}

\begin{tabular}{lcc}
\hline \multicolumn{1}{c}{ Kegiatan } & WISN & $\begin{array}{c}\text { Standar } \\
\text { Beban Kerja } \\
\text { (Menit) }\end{array}$ \\
\hline $\begin{array}{l}\text { Melayani } \\
\text { pendaftaran pasien } \\
\text { RJ dan IGD }\end{array}$ & $\frac{117.180}{7}$ & 16.740 \\
\hline $\begin{array}{l}\text { Melayani } \\
\text { pendaftaran pasien } \\
\text { RI }\end{array}$ & $\frac{117.180}{15}$ & 7.812 \\
\hline
\end{tabular}

Berdasarkan tabel $\mathrm{VI}$, hasil perhitungan menggunakan metode WISN standar beban kerja yang dibutuhkan petugas pendaftaran pasien untuk melayani pendaftaran pasien RJ dan IGD adalah 16.740 menit per tahun sedangkan untuk melayani pendaftaran pasien $\mathrm{RI}$ adalah 7.812 menit per tahun.

b. Pelaporan

\section{Tabel VII}

\begin{tabular}{lccc}
\hline \multicolumn{1}{c}{ Kegiatan } & $\begin{array}{c}\text { Satuan } \\
\text { (per } \\
\text { tahun) }\end{array}$ & $\begin{array}{c}\text { Kuant } \\
\text { itas }\end{array}$ & $\begin{array}{c}\text { Rata- } \\
\text { rata } \\
\text { Waktu } \\
\text { Perkegi } \\
\text { atan } \\
\text { (Menit) }\end{array}$ \\
\hline $\begin{array}{l}\text { Melakukan sensus } \\
\text { harian RI }\end{array}$ & Kali & I.320 & 3 \\
\hline Pegentrian status RI & Pasien & I.320 & 2 \\
\hline Pengentrian status RJ & Pasien & $\begin{array}{c}25.9 \mathrm{I} \\
0\end{array}$ & 2 \\
\hline
\end{tabular}

\section{Tabel VIII}

\begin{tabular}{lcc}
\hline \multicolumn{1}{c}{ Kegiatan } & WISN & $\begin{array}{c}\text { Standar Beban } \\
\text { Kerja (Menit) }\end{array}$ \\
\hline $\begin{array}{l}\text { Melakukan sensus } \\
\text { harian RI }\end{array}$ & $\frac{117.180}{3}$ & 39.060 \\
\hline $\begin{array}{l}\text { Pegentrian status } \\
\text { RI }\end{array}$ & $\frac{117.180}{2}$ & 58.590 \\
\hline $\begin{array}{l}\text { Pengentrian } \\
\text { status RJ }\end{array}$ & $\frac{117.180}{2}$ & 58.590 \\
\hline
\end{tabular}

Berdasarkan tabel VIII, hasil perhitungan menggunakan metode WISN standar beban kerja yang dibutuhkan petugas pelaporan untuk melakukan sensus harian $\mathrm{RI}$ adalah 39.060 menit/tahun serta untuk pengentrian status $\mathrm{RI}$ adalah 58.590 menit/tahun sedangkan untuk pengentrian status RJ adalah 58.590 menit/tahun 
c. Coding

\section{Tabel IX}

\begin{tabular}{lccc}
\hline Kegiatan & $\begin{array}{c}\text { Satuan } \\
\text { (per } \\
\text { tahun) }\end{array}$ & Kuantitas & $\begin{array}{c}\text { Rata-rata } \\
\text { Waktu } \\
\text { Perkegiatan } \\
\text { (Menit) }\end{array}$ \\
\hline $\begin{array}{l}\text { Pengkodean } \\
\text { penyakit RJ } \\
\text { pada } \\
\text { database }\end{array}$ & Pasien & 25.910 & $\mathrm{I}$ \\
\hline $\begin{array}{l}\text { Pengkodean } \\
\text { penyakit RI } \\
\text { pada } \\
\text { database }\end{array}$ & Pasien & 1.320 & 5 \\
\hline $\begin{array}{l}\text { Pengkodean } \\
\text { penyakit RI } \\
\text { pada DRM }\end{array}$ & Pasien & 1.320 & $\mathrm{I}$ \\
\hline
\end{tabular}

\section{Tabel X}

\begin{tabular}{lcc}
\hline \multicolumn{1}{c}{ Kegiatan } & WISN & $\begin{array}{c}\text { Standar } \\
\text { Beban Kerja } \\
\text { (Menit) }\end{array}$ \\
\hline $\begin{array}{l}\text { Pengkodean } \\
\text { penyakit RJ pada } \\
\text { database }\end{array}$ & $\frac{117.180}{1}$ & $\mathrm{I} 17.180$ \\
\hline $\begin{array}{l}\text { Pengkodean } \\
\text { penyakit RI pada } \\
\text { database }\end{array}$ & $\frac{117.180}{5}$ & 23.436 \\
\hline $\begin{array}{l}\text { Pengkodean } \\
\text { penyakit RI pada } \\
\text { DRM }\end{array}$ & $\frac{117.180}{1}$ & $\mathrm{I} 17.180$ \\
\hline
\end{tabular}

Berdasarkan tabel $X$ hasil perhitungan menggunakan metode WISN standar beban kerja yang dibutuhkan petugas coding untuk melakukan pengkodean penyakit RJ pada database adalah II7.180 menit/tahun serta untuk pengkodean penyakit RI pada database adalah 23.436 menit/tahun sedangkan untuk pengkodean penyakit RI pada DRM adalah I I7.| 80 menit/ tahun.

d. Filing dan Distribusi

Tabel XI

\begin{tabular}{lccc}
\hline Kegiatan & $\begin{array}{c}\text { Satuan } \\
\text { (per } \\
\text { tahun) }\end{array}$ & Kuantitas & $\begin{array}{c}\text { Rata-rata } \\
\text { Waktu } \\
\text { Perkegiatan } \\
\text { (Menit) }\end{array}$ \\
\hline $\begin{array}{l}\text { Mengambil } \\
\text { DRM }\end{array}$ & Berkas & \\
$\begin{array}{l}\text { pasien } \\
\text { kunjungan }\end{array}$ & B & 2 \\
RJ & & \\
\hline $\begin{array}{l}\text { Mengantar } \\
\text { status RJ } \\
\text { ke poli }\end{array}$ & Berkas & 25.910 & I \\
\hline
\end{tabular}

\begin{tabular}{|c|c|c|c|}
\hline $\begin{array}{l}\text { Mencatat } \\
\text { status RJ } \\
\text { yang telah } \\
\text { kembali di } \\
\text { buku } \\
\text { register }\end{array}$ & Berkas & 25.910 & I \\
\hline $\begin{array}{l}\text { Mengemba } \\
\text { likan } \\
\text { status RJ } \\
\text { yang telah } \\
\text { kembali }\end{array}$ & Berkas & 25.910 & 2 \\
\hline
\end{tabular}

\section{Tabel XII}

\begin{tabular}{lcc}
\hline \multicolumn{1}{c}{ Kegiatan } & WISN & $\begin{array}{c}\text { Standar } \\
\text { Beban } \\
\text { Kerja } \\
\text { (Menit) }\end{array}$ \\
\hline $\begin{array}{l}\text { Mengambil DRM } \\
\text { pasien kunjungan RJ }\end{array}$ & $\frac{117.180}{2}$ & 58.590 \\
\hline $\begin{array}{l}\text { Mengantar status RJ } \\
\text { ke poli }\end{array}$ & $\frac{117.180}{1}$ & II7.180 \\
\hline $\begin{array}{l}\text { Mencatat status RJ } \\
\text { yang telah kembali di } \\
\text { buku register }\end{array}$ & $\frac{117.180}{1}$ & $\mathrm{II} 7.180$ \\
\hline $\begin{array}{l}\text { Mengembalikan status } \\
\text { RJ yang telah kembali }\end{array}$ & $\frac{117.180}{2}$ & 58.590 \\
\hline
\end{tabular}

Berdasarkan tabel XII hasil perhitungan menggunakan metode WISN standar beban kerja yang dibutuhkan petugas filing untuk mengambil DRM pasien kunjungan RJ adalah 58.590 menit per tahun, serta untuk petugas didtribusi mengantar status RJ ke poli adalah II7.180 menit/tahun, untuk petugas filing mencatat status RJ yang telah kembali di buku register adalah II 7.180 menit/tahun sedangkan untuk mengembalikan status RJ yang telah kembali adalah 58.590 menit/tahun.

\section{Perhitungan Standar Kelonggaran (SK)}

\section{Petugas Rekam Medis}

a. Faktor kelonggaran I (rapat)

Rata - rata rapat yang dilaksanakan dengan durasi waktu 4 jam sebanyak I kali dalam I bulan. 4 jam $\times 12$ bulan $=48$ jam/tahun atau setara dengan 2.880 menit/tahun

Jadi SK Rata-rata waktu kelonggaran untuk rapat $=$ 


\section{Waktu kerja tersedia \\ 2.880 menit/tahun \\ I I7.180 menit/tahun \\ $=0,02$ tenaga kerja}

Berdasarkan hasil metode perhitungan

WISN faktor kelonggaran I yang dibutuhkan petugas rekam medis adalah 0,02 tenaga kerja.

b. Faktor kelonggaran 2 (Ishoma)

Ishoma dilakukan oleh unit rekam medis dengan durasi rata - rata I jam per hari atau 365 jam per tahun atau setara dengan 21.900 menit/tahun

Jadi SK Rata-rata waktu kelonggaran untuk = -------------------

$$
\begin{aligned}
& \frac{21.900 \text { menit/tahun }}{117.180 \text { menit/tahun }} \\
= & 0,18 \text { tenaga } \text { kerja }
\end{aligned}
$$

Berdasarkan hasil metode perhitungan WISN faktor kelonggaran 2 yang dibutuhkan petugas rekam medis adalah 0,18 tenaga kerja.

Standar Rata-rata waktu kelonggaran Kelonggaran $=$

Waktu kerja tersedia

$$
=\frac{0,02+0,18}{117.180 \text { menit/tahun }}
$$

$$
=\frac{0.2}{\text { I } 17.180 \text { menit/tahun }}
$$

$=\quad 1.70$ tenaga kerja

Jadi hasil dari kedua faktor kelonggaran petugas rekam medis standar kelonggaran yang dibutuhkan adalah 1.70 tenaga kerja.

\section{Perhitungan Kebutuhan Tenaga Kerja Petugas Rekam Medis}

Tabel XIII

\begin{tabular}{llll}
\hline No. & Kunjungan Pasien & $\begin{array}{l}\text { Jumlah } \\
\text { Pasien } \\
\text { (orang) }\end{array}$ & $\begin{array}{l}\text { Persentase } \\
\text { (\%) }\end{array}$ \\
\hline I. & Pasien Rawat Inap & 1.320 & 20 \\
\hline 2. & Pasien Rawat Jalan & 25.910 & 80 \\
\hline TOTAL & 27.230 & 100 \\
\hline
\end{tabular}

a. Tempat Pendaftaran Pasien (TPP)

\section{Tabel XIV}

\begin{tabular}{|l|c|c|}
\hline \multicolumn{1}{|c|}{ Kegiatan } & WISN & Kebutuhan SDM \\
\hline $\begin{array}{l}\text { Melayani } \\
\text { pendaftaran pasien } \\
\text { RJ dan IGD }\end{array}$ & $\frac{25.910}{16.740}$ & $\mathrm{I} .53$ \\
\hline $\begin{array}{l}\text { Melayani } \\
\text { pendaftaran pasien } \\
\text { RI }\end{array}$ & $\overline{1.320}$ & \\
\hline Jumlah & 7.812 & 0.16 \\
\hline $\begin{array}{l}\text { Total Kebutuhan } \\
\text { SDM }\end{array}$ & $\mathrm{I} .69+\mathrm{I} .70$ & $\mathrm{I} .69$ \\
\hline
\end{tabular}

Pada tabel XV perhitngan menggunakan metode WISN diperoleh kebutuhan tenaga kerja untuk pelaporan adalah 4.42 atau 4 tenaga kerja.

\begin{tabular}{|c|l|c|c|}
\hline No & \multicolumn{1}{|c|}{ Kegiatan } & WISN & $\begin{array}{c}\text { Kebutuhan } \\
\text { SDM }\end{array}$ \\
\hline I & $\begin{array}{l}\text { Pengkodean penyakit } \\
\text { RJ pada database }\end{array}$ & $\frac{25.910}{117.180}$ & 0.22 \\
\hline 2 & $\begin{array}{l}\text { Pengkodean penyakit } \\
\text { RI pada database }\end{array}$ & $\frac{1.320}{23.436}$ & 0.05 \\
\hline 3 & $\begin{array}{l}\text { Pengkodean penyakit } \\
\text { RI pada DRM }\end{array}$ & $\frac{1.320}{117.180}$ & 0.01 \\
\hline Jumlah & 0.28 \\
\hline \multicolumn{2}{|l|}{ Total Kebutuhan SDM } & $0.28+1.70$ & 1.98 \\
\hline
\end{tabular}

Berdasarkan tabekI XIV hasil perhitungan menggunakan metode WISN diperoleh kebutuhan tenaga kerja tempat pendaftaran pasien adalah 3.39 tenaga kerja atau 3 tenaga kerja.

b. Pelaporan

\section{Tabel XV}

\begin{tabular}{|c|l|c|c|}
\hline No & \multicolumn{1}{|c|}{ Kegiatan } & WISN & $\begin{array}{c}\text { Kebutuhan } \\
\text { SDM }\end{array}$ \\
\hline I & $\begin{array}{l}\text { Pengkodean penyakit } \\
\text { RJ pada database }\end{array}$ & $\frac{1.320}{39.060}$ & 0.03 \\
\hline 2 & $\begin{array}{l}\text { Pengkodean penyakit } \\
\text { RI pada database }\end{array}$ & $\frac{1.320}{58.590}$ & 2.25 \\
\hline 3 & $\begin{array}{l}\text { Pengkodean penyakit } \\
\text { RI pada DRM }\end{array}$ & $\frac{25.910}{58.590}$ & 0.44 \\
\hline Jumlah & 2.72 \\
\hline \multicolumn{2}{|l|}{ Total Kebutuhan SDM } & $2.72+1.70$ & 4.42 \\
\hline
\end{tabular}

\section{c. Coding}

\section{Tabel XVI}

\begin{tabular}{|c|c|c|c|}
\hline No & Kegiatan & WISN & $\begin{array}{c}\text { Kebutuhan } \\
\text { SDM }\end{array}$ \\
\hline
\end{tabular}




\begin{tabular}{|c|l|c|c|}
\hline I & $\begin{array}{l}\text { Pengkodean penyakit } \\
\text { RJ pada database }\end{array}$ & $\frac{25.910}{117.180}$ & 0.22 \\
\hline 2 & $\begin{array}{l}\text { Pengkodean penyakit } \\
\text { RI pada database }\end{array}$ & $\frac{1.320}{23.436}$ & 0.05 \\
\hline 3 & $\begin{array}{l}\text { Pengkodean penyakit } \\
\text { RI pada DRM }\end{array}$ & $\frac{1.320}{117.180}$ & 0.01 \\
\hline \multicolumn{2}{|l|}{ Jumlah } & $0.28+1.70$ & 1.984 .42 \\
\hline \multicolumn{2}{|l|}{ Total Kebutuhan SDM } \\
\hline
\end{tabular}

Berdasarkan tabel XVI hasil perhitungan menggunakan metode WISN diperoleh kebutuhan tenaga kerja untuk coding adalah 1.98 tenaga kerja atau 2 tenaga kerja.

d. Filing dan Distribusi

\section{Tabel XVII}

\begin{tabular}{|c|l|c|c|}
\hline No & \multicolumn{1}{|c|}{ Kegiatan } & WISN & $\begin{array}{c}\text { Kebutuhan } \\
\text { SDM }\end{array}$ \\
\hline I & $\begin{array}{l}\text { Mengambil DRM } \\
\text { pasien kunjungann RJ }\end{array}$ & $\frac{25.910}{58.590}$ & 0.44 \\
\hline 2 & $\begin{array}{l}\text { Mengantar statusRJ ke } \\
\text { poli }\end{array}$ & $\frac{25.910}{58.590}$ & 0.44 \\
\hline 3 & $\begin{array}{l}\text { Mencatat status RJ } \\
\text { yang telah kembali di } \\
\text { buku register }\end{array}$ & $\overline{25.910}$ & 0.44 \\
\hline 4 & $\begin{array}{l}\text { Mengembalikan status } \\
\text { RJ yang telah kembali }\end{array}$ & $\frac{25.910}{58.590}$ & 0.44 \\
\hline Jumlah & 0.76 \\
\hline \multicolumn{2}{|l|}{ Total Kebutuhan SDM } & $0.76+1.70$ & 3.46 \\
\hline
\end{tabular}

Berdasarkan table XVII hasil perhitungan menggunakan

metode WISN diperoleh kebutuhan tenaga kerja untuk petugas filling dan distribusi adalah 3.46 tenaga kerja atau 3 tenaga kerja.

\section{PEMBAHASAN}

Hasil penelitian tentang perhitungan waktu kerja tersedia pada petugas rekam medis Klinik Rawat Inap Ramdani Husada tidak sesuai dengan metode perhitungan WISN menurut Departemen Kesehatan (2004). Hal ini dibuktikan dengan tidak adanya data yang digunakan untuk perhitungan waktu kerja tersedia yang sesuai dengan metode WISN yaitu hari kerja (A), cuti tahunan (B), pendidikan dan pelatihan (C), hari libur nasional (D), ketidakhadiran kerja (E) dan waktu kerja (F). Menetapkan waktu kerja tersedia tujuannya adalah memperoleh waktu kerja tersedia masing-masing kategori tenaga kerja yang bekerja selama kurun waktu satu tahun.

Penetapan unit kerja dan kategori tenaga kerja belum sesuai dengan metode perhitungan WISN menurut
Departemen Kesehatan (2004), hal ini didukung dengan tidak adanya petugas dengan kualifikasi Pendidikan Rekam Medis Informasi Kesehatan. Penetapan kategori tenaga kerja pada petugas rekam medis sangat peting karena kegiatan rekam medis berpengaruh pada pelayanan dan kepuasan pasien.

Menurut perhitungan standar beban kerja pada petugas rekam medis Klinik Rawat Inap Ramdani Husada tidak sesuai dengan metode perhitungan WISN menurut Departemen Kesehatan (2004), hal ini dikarenakan manager klinik tidak melakukan perhitungan standar beban kerja pada petugas rekam medis Klinik Rawat Inap Ramdani Husada. Perhitungan beban kerja sangat penting karena salah satunya dapat menngetahui prosedur kerja yang lebih efisien serta menetapkan jumlah tenaga kerja dan peralatan kerja.

Berdasarkan standar kelonggaran yang dilakukan petugas rekam medis Klinik Rawat Inap Ramdani Husada yaitu rapat, dan Ishoma. Dimana rapat sebesar 0,02 tenaga kerja, dan Ishoma sebesar 0, 18 tenaga kerja untuk standar kelonggaran yang dibutuhkan sebesar I,70 tenaga kerja.Hasil perhitungan standar kelonggaran petugas rekam medis di Klinik Rawat Inap Ramdani Husada tidak sesuai dengan metode perhitungan WISN menurut Departemen Kesehatan (2004).

Hasil perhitungan kebutuhan tenaga kerja petugas rekam medis belum sesuai dengan keadaan petugas saat ini. Berdasarkan Berdasarkan Kepmenkes RI No. 8I/Menkes/SK/I/2004 tentang Pedoman Penyusunan Perencanaan Sumber Daya Manusia Kesehatan di Tingkat Propinsi, Kabupaten/Kota serta rumah Sakit dinyatakan bahwa perencanaan SDM kesehatan ditujukan pada perhitungan kebutuhan SDM kesehatan untuk memenuhi kebutuhan pada sarana pelayanan kesehatan seperti puskesmas, rumah sakit, poliklinik, dan lain-lainnya. Oleh sebab itu, perencanaan kebutuhan SDM bukanlah kegiatan yang ringan. Hal ini dikarenakan perhitungan kebutuhan SDM harus menggunakan metode perhitungan yang berdasarkan pada beban pekerjaan nyata yang dilaksanakan oleh tiap kategori 
SDM kesehatan pada tiap unit kerja di fasilitas pelayanan kesehatan. Metode tersebut haruslah mudah dioperasikan, mudah digunakan, secara teknis mudah diterapkan, komprehensif, dan realistis. Metode yang sesuai dengan kondisi tersebut adalah metode perhitungan kebutuhan SDM berdasarkan beban kerja (WISN). Menurut Peraturan Menteri Dalam Negeri nomor 12 tahun 2008 tentang Pedoman Analisis Beban Kerja Di Lingkungan Departemen Dalam Negeri dan Pemerintah Daerah (Ningsih, 2012), analisis beban kerja dilaksanakan untuk mengukur dan menghitung beban kerja setiap jabatan atau unit kerja dalam rangka efisiensi dan efektivitas pelaksanaan tugas dan meningkatkan kapasitas organisasi yang profesional, transparan, proposional, dan rasional. Selain itu, menurut penelitian Suharyono dan Adisasmito (2006), kelebihan penghitungan tenaga kesehatan menggunakan metode WISN adalah lebih fokus pada penghitungan kebutuhan tenaga kesehatan serta menyesuaikan dengan uraian pekerjaan yang ada pada unit kerja yang akan diteliti sehingga diperoleh hasil yang sesuai dengan beban kerja berdasarkan uraian pekerjaannya. Pengalokasian tenaga kerja yang kurang maksimal yang dapat ditinjau dari kinerja rekam medis di klinik dapat disarankan untuk mempertimbangkan beberapa aspek petugas dalam perencanaan tenaga kerja, agar dapat meningkatkan produktifitas kerja serta menurunkan risiko kelelahan pada petugas. Ketersediaan tenaga kerja dengan jumlah yang cukup dan kualitas yang tinggi serta profesional sesuai dengan fungsi dan tugasnya merupakan salah satu indikator keberhasilan rumah sakit yang efektif dan efisien (Wijaya, 20I4).

\section{KESIMPULAN}

Kebutuhan tenaga kerja rekam medis pada petugas pendaftaran pasien menggunakan metode WISN di Klinik Rawat Inap Ramdani Husada mebutuhkan sebanyak 9 orang petugas dengan 4 pembagian sub kerja yaitu tempat pendaftaran pasien, coding, filing dan distribusi, serta pelaporan, dengan menggunakan kaidah
Kepmenkes No. 8I/Menkes/SK/I/2004. Tentu saja, penambahan SDM tersebut juga dengan mempertimbangkan kualifikasi dan kompetensi tenaga di bidang rekam medis agar tertib administrasi pada pengelolaan rekam medis semakin baik. Saran dari penelitian ini, sebaiknya dalam perencanaan mendatang Klinik Rawat Inap Ramdani Husada memiliki sistem informasi ketenagaan yang baik sehingga dapat menjadi landasan dalam mengajukan permintaan penambahan SDM kesehatan.

\section{REFERENSI}

I. DepKes, 2004. Keputusan Menteri Kesehatan Republik Indonesia Nomor: 8I/Menkes/SK/I/2004 tentang Pedoman Penyusunan Perencanaan Sumber Daya Manusia Kesehatan Di Tingkat Propinsi, Kabupaten/Kota serta Rumah Sakit

2. Keputusan Menteri Kesehatan Republik Indonesia Nomor: 8I/Menkes/SK/I/2004 tentang Pedoman Penyusunan Perencanaan Sumber Daya Manusia Kesehatan Di Tingkat Propinsi, Kabupaten/Kota serta Rumah Sakit

3. Ningsih, D.W. 2012. Perencanaan Kebutuhan Petugas Rekam Medis Berdasarkan Uraian Pekerjaan Sebagai Dasar Pengambilan Keputusan Di Rumah Sakit Grhasia Yogyakarta tahun 2012. Tugas Akhir. D-3 Rekam Medis Sekolah Vokasi UGM.

4. Notoatmodjo, Soekidjo. 2010. Metodologi Penelitian Kesehatan. Jakarta : Rineka Cipta.

5. Sugiyono. 20I I. Statistika Untuk Penelitian. Bandung : CV Alfabeta

6. Saputri V.W, Misnaniarti, Ainy A. 2009. Perencanaan Kebutuhan Sumber Daya Manusia Kesehatan Dengan Metode Workload Indicators Of Staffing Need (WISN) Di Puskesmas Merdeka Kota Palembang Tahun 2009. Tersedia di alamat http://eprints.unsri.ac.id/65/.

7. Suharyono M. W. dan AdisasmitoWiku B.B. (2006). Analisis Jumlah Kebutuhan Tenaga Pekarya Dengan Work Sampling Di Unit Layanan Gizi Pelayanan Kesehatan Saint Carolus. Tersedia di alamat http://staff.blog.ui.ac.id/wikua/files/2009/10/analisis-jmlkebutuhantenagapekarya-dengan-work-samplingout.pdf.

8. Wijaya, Novita Feni. 20I4. Tinjauan Kebutuhan Tenaga Berdasarkan Beban Kerja Unit Rekam Medis Di Rumah Sakit Islam Unisma Malang. (tidak dipublikasikan 